\title{
Management of Pre-University Education Schools in the New Century - The Case of Albania
}

\author{
Bukurie Kallanxhi (Haxhia) \\ PhD Candidate \\ Dr. Valbona Cinaj \\ Manuela Meçe \\ Prof. Asoc. Dr.
}

\begin{abstract}
The main objective of this paper is to provide professional knowledge and practical ideas so we can understand them more easily and apply them in the teaching and management practice of the school. The aim of this paper is to help us understand the changes that occur in education by trying to reflect social developments and adapt them more easily to the requirements of new curricula, new teaching methodology and the inclusion of new technology in schools. This paper is based on literature review, and empirical treatment through the processing of statistical data enabled through surveys, questionnaires and interviews to explore experiences and perceptions of the role of leader and teacher in pre-university education schools in the new century. All schools of pre-university education in Albania have been part of this study.
\end{abstract}

Keywords: school management, pre-university education, director

\section{Introduction}

Education generates collective benefits, called positive externalities, which far outweigh individual benefits (Horvath, 2007). These collective benefits include the economic growth of a country, the ability to innovate and compete, as well as social cohesion and shared values. They are usually not considered by individuals who, having to pay to attend school or university, would therefore complete education levels that are too low to maximize collective benefits. Expressed in economic terms, this is a case of market failure and state education is required to bring private costs and benefits in line with social costs and benefits. From this point of view, education is a public good: it requires state intervention. There is a common denominator between different approaches to the public good (standard definition as well as alternative conceptualizations of education as a public good). 


\section{Methodology}

This paper is based on the review of a wide range of socio-psychological and pedagogical literature on our continent but also worldwide related to school management treatments. They are brought with a descriptive and comparative analysis with the experience and practices applied in Albania. For the realization of the work, the basic research methods in social sciences have been used, such as survey, interviewing, observation of phenomena in the fields included in this project, case study, etc.

Qualitative data are provided through interviews with: 1) experts and individuals with experience in this field, leaders of educational institutions, associations, etc. ; 2) focus groups with 5-10 individuals in three categories: students, teachers, parents and citizens, etc. ; 3) writing, on free discussion issues about teaching and teachers based on open survey questions;

Quantitative data are provided through the sampling survey method. The survey was closed- ended (with pre-determined alternatives to answers). The surveys were completed individually by the respondents, or by the respondents according to the face-to-face principle, ensuring that the survey was anonymous. The selection of respondents was carried out in accordance with the sampling criteria, respecting especially the randomness criterion, but at the same time adhering to the oriented method. While the random method was performed with the aim that, within the above frameworks, the selection of concrete individuals that constituted the study sample was quite random. The basis for the survey were inhabited centers (in cities, or villages), as well as institutions, mainly schools. The survey was conducted in schools in 12 regions of Albania, in reports corresponding to their population (based on INSTAT data). The study population was about 50 schools (30 of basic education and 20 of secondary education), where over 300 school principals, 500 teachers, 250 parents, and 1000 students were surveyed.

\section{Literature Review}

Currently, educational institutions are focusing on new job skills and habits and in a different way of thinking, creative and critical thinking. Critical thinking is a complex process of integrating ideas and resources creatively, conceptualizing and restructuring concepts and information (Gardner, 2003; Peshkepia, "On School Administration", lectures, 2012). Creative thinking is the ability to generate alternatives, to consider different factors, it is a necessary complement to critical thinking. Critical and creative thinking skills are not acquired by chance. They are acquired during a long and continuous process.

The essence of contemporary teaching modifies roles. The teacher already directs, guides, guides, talks, discusses, exchanges ideas. The student, who previously had the function of answering when asked, listening and reproducing information, has gone into involvement, into action. It can be said that the teacher and the student have 
become co-authors of the lesson. Here there is room to deepen learning and learning, intertwining them, learning with themes of learning with projects, which provide a massive activation of students (ISP \& UNESCO, 2003; Institute of Curriculum and Training, Direction of school, guide for school leaders, 2008).

Gardner points out that by definition, a skilled teacher is one who, for the same concept, can open a different number of windows ... A successful teacher serves as a "mediator between the student and the curriculum", always ready for educational prosthetics - texts, movies, computer software - which can help explain the content, in the most effective way possible, for students who display characteristics for this form of learning "(Howard Gardner: On Teaching for Understanding : A Conversation with Howard Gardner, 1993) He adds: "It doesn't matter how smart you are, but it does matter what you are smart about" and, according to him, we, as human beings, all have the ability to solve problems of different kinds. Each subject has its own learning style and a single form of intelligence. Every subject, even if there is a shortcoming, can have a self-original and original way of knowing.

"Progressive philosophy and humanist education increase the student's selfawareness and self-awareness, help him personalize and individualize learning, and align (at least assess) his own personal needs and interests with academic experiences (Orstein, 2003).

The class is characterized by activity, not passivity; from cooperation, not competition; and many opportunities to learn, in addition to teacher-led textbooks and situations."

"Today the teacher is generally only a leader or a sifter of the imagination that pervades the child's soul ..., the teacher's task today is to encourage his judgment to distinguish the existent from the non-existent (non-existent) by pushing him to selfaction ... The more interest a lesson has, the more self-action is encouraged ... interest and self-action are in direct proportion." (Sydney Finkelstein "The Best Leaders Are Great Teachers" 2018).

\subsection{School planning and management strategies}

The main task of the teacher is to build functional lessons, teaching activities, which are related to and in function of the qualitative realization of certain objectives in the strategies and on the teaching and school platforms.

In each lesson the teacher guides himself and the students which method is more fruitful, makes a scheme of how to realize the lesson so that knowledge learning is productive and in accordance with school objectives (MES \& Save_the_Children, Manual school self-assessment , 2007).

If new teachers are required to prepare the lesson every day, make it as analytical as possible and clearly define the step they will take, both in teaching and learning, older, experienced teachers use it. to proceed during the lesson. 
This, of course, does not exclude that this type of teacher does not functionally prepare the daily platform and be clearly oriented through the "labyrinths" of the lesson, in the reports that can be created during it (Council_of_Europe, Policies and practicies for teaching sociocultural diversity - A survey report., 2008).

Later, with professional training and the environment of the role and task of the teacher, planning should be organized in accordance with the characteristics of the students, with the problems that they may present (Peshkepia, "On school administration", lectures, 2012).

The innovations of the teacher's work are related to his permanent qualification, as well as to the application of various active methods, reaching a conviction of what are those techniques and methods that are fruitful, encourage the student to learn, to take actively participating in the learning process, promote his independent work step by step he gains a logical reasoning in the elaboration of transmitted knowledge (Kraja, 2008).

Planning and preparation of the lesson, its planning is closely related to the way the lesson is realized. This makes the teacher clearer and the structuring of the lesson brings guarantees in the necessary time for each stage and task of the lesson developed in the classroom.

\subsection{Perspectives on School management}

Experience has shown that the higher the demands of society, the greater and more delicate the role of the leader. It is now clear to everyone that quality assurance is guaranteed only through effective management of all work carried out in the relevant institution. The direction in which it is spoken and sought must be both dynamic and democratic. Only in this way can he set the tone for school life and the activity of active organisms, offering all actors new opportunities and visions (H, 2003; Muka, 1995; Pollard \& Tann, 2000). According to Ronald T. Hyman, "Modern management sees the manager as a far-sighted person, constantly in touch with his staff, trying to make all employees feel good, develop and apply their skills to the fullest; it leads staff to selfimprovement, to understanding them, and to using effective forms of communication. " According to him, the leader should serve as a model by transmitting to others with words and actions, clear messages on how we should treat each other.

Everywhere today there is talk and a modern direction is required. There are various theories and philosophies about this. Terms such as: "democratic direction", "scientific direction", "cooperation and teamwork", etc., prove that time has gone to the autocratic direction. In the new democratic system all teaching staff should participate in the most important decisionmaking, every teacher should feel part of the team (ISP \& UNESCO, 2003).

Researcher Lovell says that the contemporary leader should use as many motivating elements as possible, so that the staff can experience a sense of belonging to the institution where they work and feel proud of it. It is not enough to know and express 
these norms with eloquence, but also to apply them, so that not only pleasant slogans remain, but a reality. It is not uncommon for certain leaders to use terms and phrases that sound democratic, while in everyday life and practice they operate with authoritarianism, arrogance, point to personal cult, or manipulate staff to achieve certain goals. (Michael Lovell "Higher Education - Lovell on Innovating Education and Looking Ahead")

It often happens that executives ask for a "homogeneous" team of a cut, that of the boss's module, while they have to look for a heterogeneous staff. A modern and contemporary direction means establishing and ensuring a relationship of mutual trust between all staff members, sharing the burden, responsibilities and authority, raising awareness and compacting a dynamic group of winners. Staff work is successful when each teacher is valued as a valuable individual, a potential winner, who makes special contributions to the well-being of the entire team (Horvath, 2007; Musai, 2000; Wende, 2000). In these circumstances, the relationship between the staff is open, friendly and not "official", mutual trust and respect for the individual are seen as essential.

And, in all these give and take, the first model must be the leader. Through the management methods and management projects he implements in his workplace, to create a genuine positive atmosphere, he enables everyone to have many chances of success, to create a space to feel free to try their ideas, to experiment with new forms of work, without shyness even though they may be wrong. Moreover, they consider mistakes to be a valuable opportunity to improve their work and professional development. I think that such models are not lacking today in schools, offices and educational directorates and MES departments.

Such demands, as we said above, may seem somewhat difficult for some leaders, so resistance to change is normal. Everyone is afraid of the new and the unknown. True success comes after many trials and failures. But many times, this resistance comes from professional and communication incompetence, from old and new mentalities, or from unclean motives for the role taken (MES \& Save the Children, Manual full school inspection, 2005).

Many executives understand the changes that are required to be made, but few realize them and are often tempted to engage in these practices, only by feeling well involved. Democratic governance policies today emphasize the creation of possible spaces for the involvement of young people, not only as social and political factors, as "actors of social change", but also towards active participation and promotion of youth values in social life and human energy management, thus strengthening their socioeconomic status (Curriculum and Training Institute, School Management, Guide for School Leaders, 2008).

Qualitative young people should be approached in the management system, to alternate contributions with older specialists, bringing innovation in the way of conceiving and ethics of management. Both the elderly and the young must bring a 
new spirit and experience to the governing system, according to the models of Western democracies.

Not infrequently, even today, instead of an effective leader, there is still the type of authoritarian leader who leads his staff with instructions. He commands what to do and what not to do, generates a lot of instructions, a little personal responsibility and space for initiative. These instructions are mostly knowledge about limitations, which restrict the freedom to act and stifle creativity. While the effective leader allows his staff to take initiatives and self-action. He relies on strategic leadership and becomes a visionary person, a man who gives and receives information, who inspires his colleagues (Group of authors, When Education Released the Soul, 2002). In short, the authoritarian directs his people, the effective leader inspires his people; the authoritarian relies on authority, the effective on benevolence; the authoritarian evokes fear, the effective radiates love; the authoritarian says "I", the effective says "we"; the authoritarian indicates what the error is, the effective explains the error; the authoritarian knows how to do it, the effective knows how to do it; the authoritarian demands respect, the effective imposes and enjoys respect (Gardner, 2003). The basic idea that pervades all research in the field of contemporary management is more or less as follows: leadership is the art of creating, maintaining, developing and increasing staff.

The director is the inspirer and implementer of this art. As such he must grow constantly with the team (Horvath, 2007; Musai, 2000; Wende, 2000). (Council of Europe, Policies and practices for teaching sociocultural diversity -A framework of teacher competencies for engaging With diversity „2 2010). It must become more human than its nature. On this project, in our new democratic school, the conceptual aspects, the content, the systematics and the current management styles have been reviewed. So while directing is an art, the director must be creative, actor and director. For the direction, the ways, the styles, for the leader, the skills, the qualities, the attitudes are discussed.

However, although all the modalities and old ways of evaluating professional meritocratic performance have changed, such as the reminiscence of the past, in our country, the leader and leadership in general, still continues to be clothed with power and conservative exercise of this power (Orstein , 2003). As a result, he is very greedy. There is still a great desire to take on the role of leader, but not at this level are skills, passion, qualities, efficient styles, to realize a contemporary direction of work. But now, along with the dictatorship, the myth of power has collapsed. In a democracy, leadership has descended from the Olympus of power to the realm of humanism and values.

\subsection{The role of the school principal and teacher}

The work of a school principal is balanced between being rewarding and challenging. It's a hard job, and like any job, there are people who aren't able to handle it. In addition to the obvious professional requirements required to become a director, 
there are some traits that enable good directors to perform their work successfully (Wende, 2000; Blaufusa', Mohlmannb, \& Schwabeaa, 201)).

What is highlighted is that the technological infrastructure created has given the school a greater importance for the student, without denying the fact that computers are a very important tool in the lives of young people. Effective use of new technologies that support the student's thought process increases the student's ability to focus on learning, improves comprehension and transfers content to longterm memory (Horvath, 2007; MES \& Save the Children, Manual) full school inspection, 2005). Based on this reasoning, we aim to turn traditional classes into technology-based classes.

This process requires teachers to be equipped with the appropriate technological skills and to learn to use the new technological tools that support the process of teaching students and their progress. The focus has been on the professional training of teachers to familiarize them with the latest technologies and the ability to use new technological tools that support student learning and progress (Group of Authors, Didaktika, 1986).

In addition to the traditional way of teacher professional training, on-line training will be used, through which teachers will have the opportunity to gain new skills and talk to their colleagues to share the best experiences.

Each school acts as an organization that provides society and the community with certain services in collaboration with it, aiming to solve problems step by step to continuously realize the positive changes it plans. The school lives in a certain environment and as a learning organization it must respect its social environment, as that is where the ideas come from, it is politics and partners. It is natural that the relationship between them may change. In these relationships lies the fate of school success (Institute of Curriculum and Training, Guide to the development of the new high school curriculum, 2010).

It is well known that the economic development of a society is in correlation with the level of education of the population and with the ability of that society to put its achievements in education and science in function of sustainable human development. Human development is more than the production of goods and more than the accumulation of capital, which are only means of increasing opportunities for people (ISP \& UNESCO, 2003; Institute of Curriculum and Training, Guide to the development of the new high school curriculum, 2010).

Human development is about creating the environment where man can fully develop his potential and lead a productive and creative life in accordance with his needs and interests. People are the wealth of every nation, while human development is the increase of opportunities to make a life that they desire and appreciate. 


\section{Statistical Analysis of Questionnaires/SPSS}

From the correlation table between all the variables of this study it can be stated that all the correlation coefficients are positive. This is an initial indicator that the organization, planning, implementation and management of change has had a positive impact on the integration of Albanian schools. To see if the averages of the dependent variables are biased, their histograms are observed. In the presence of outliners, they have been included to achieve unbiased descriptive statistics, as suggested by Greene (2018).

The variable student satisfaction we can see the graph 1 , as below:

Graph 1

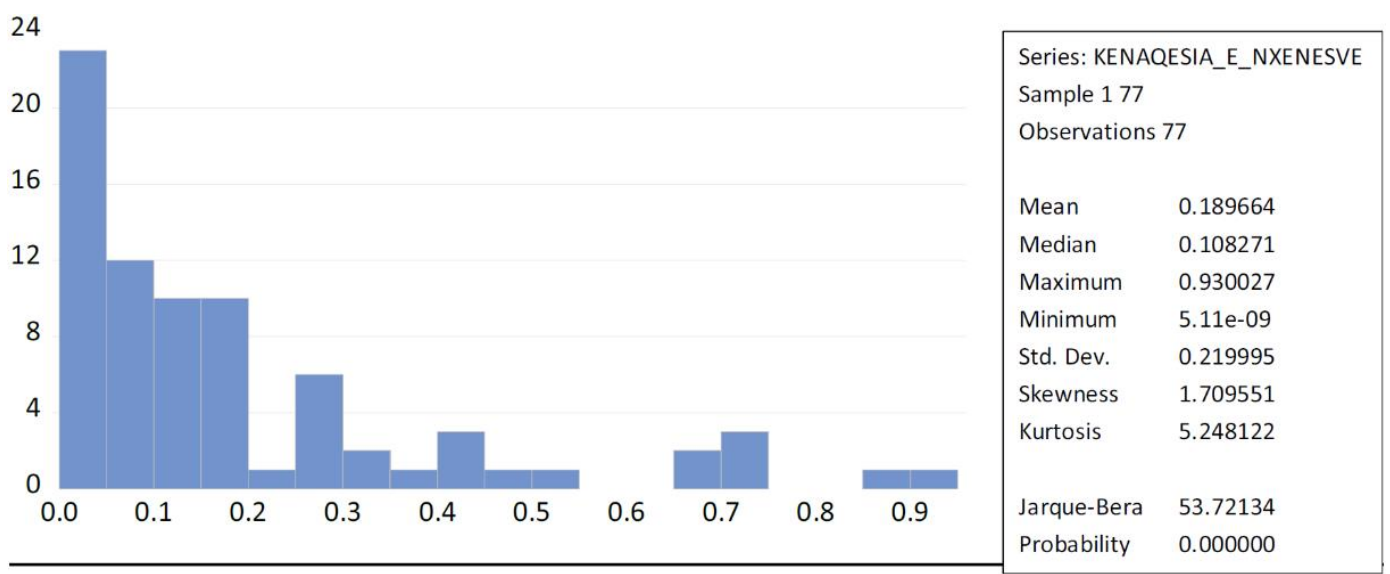

For the variable parental satisfaction, we can see the graph 2, as below: 
Graph 2

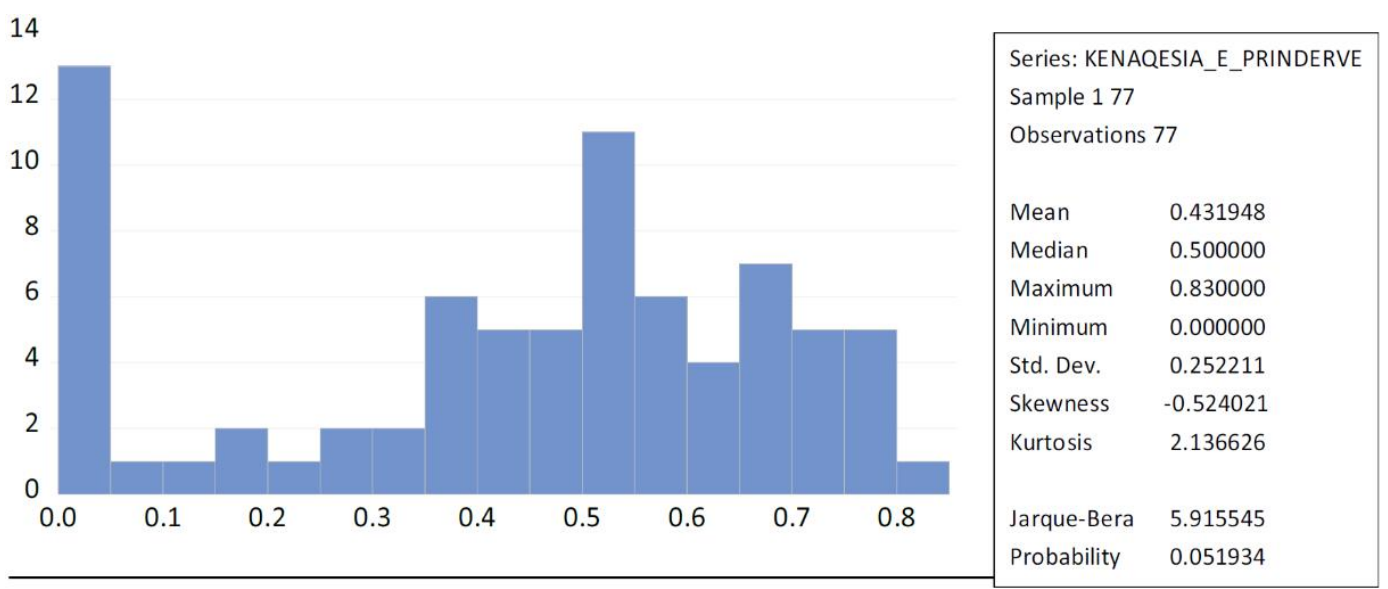

The variable teacher participation we can see in the graph 3 , as below:

Graph 3

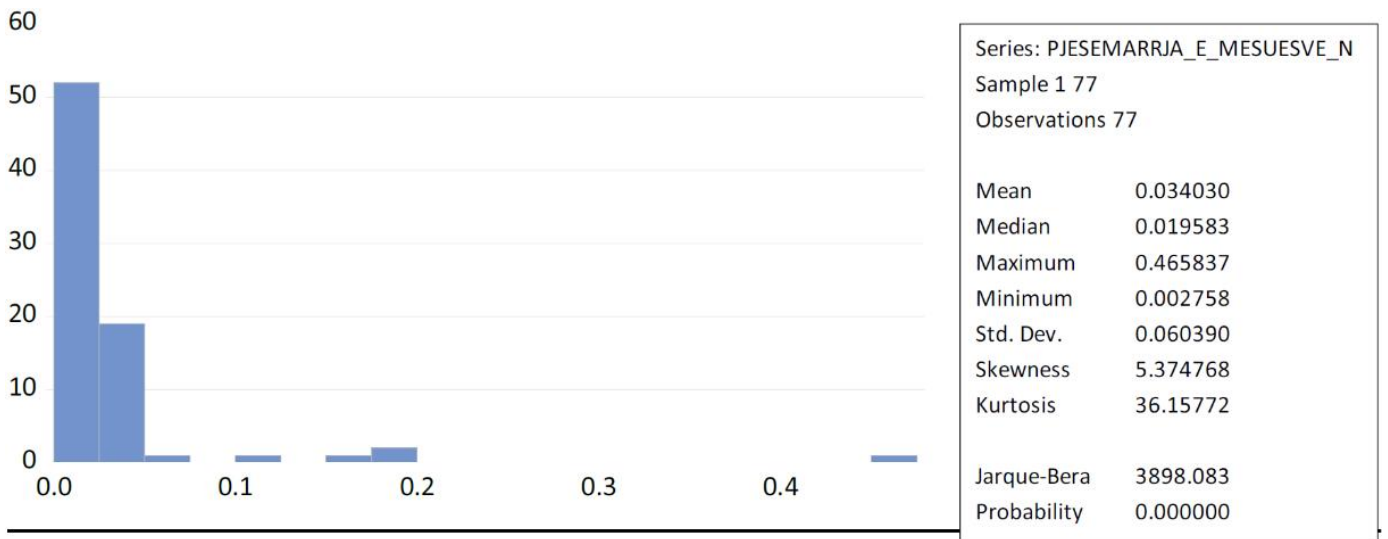

Only in the case of parental satisfaction are descriptive statistics unbiased (distribution closer to normal distribution parameters). This means that to proceed with further regressive analysis it is necessary to eliminate outliners. After eliminating the outliners, the skeiness and kurtosis parameters are expected to improve, allowing the distribution of variables to be similar to the normal distribution.

The following graph shows the average values of the three variables dependent on this study. 
Graph 4

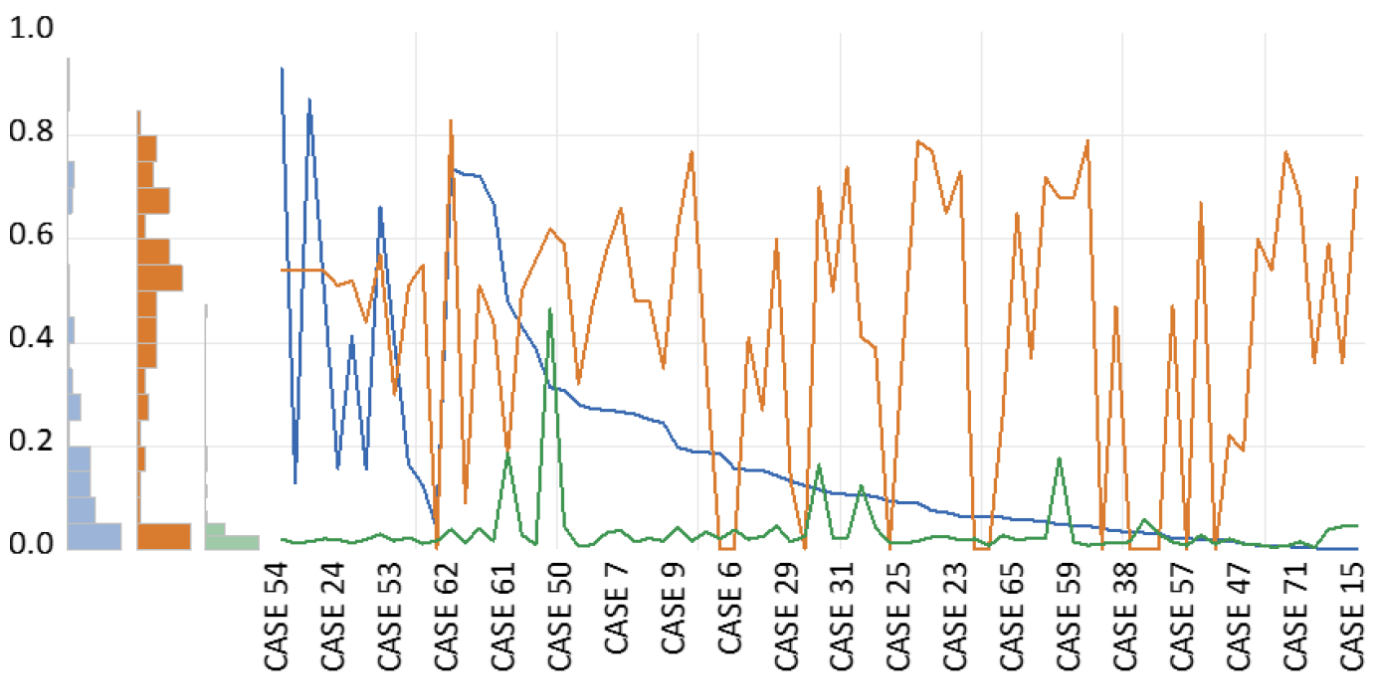

$\begin{array}{ll}- & \begin{array}{l}\text { Student satisfaction } \\ \text { Parent satisfaction }\end{array} \\ - & \text { Teacher participation }\end{array}$

From the above graph two main results can be observed: (1) parental satisfaction has a very high oscillation between the subjects asked (i.e. parents' responses to terms of satisfaction from their children's school are homogeneous by parents in parent) and (2) Teacher participation in projects is the variable with the lowest average level.

\subsection{Distribution Control}

Before deepening the regressive analysis, it is important to check whether the distribution of the dependent variables is close to the normal distribution.

In this study, quantum-quantum graphs were used to control the distribution of dependent variables (Greene, 2018) according to graph below: 
Graph 5

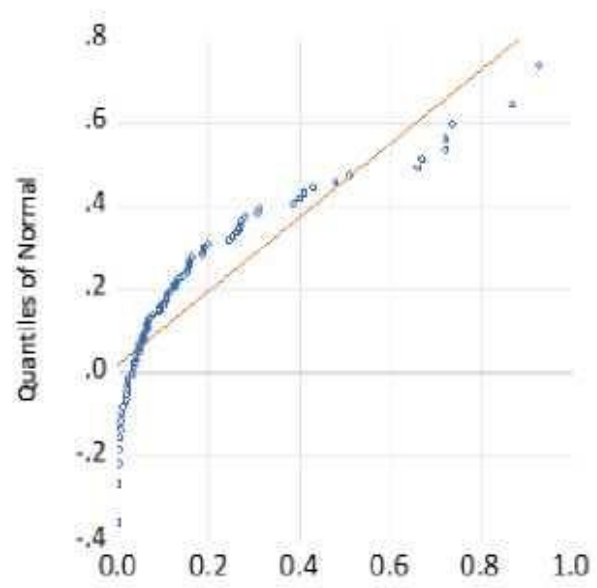

Quantiles of Students satisfaction

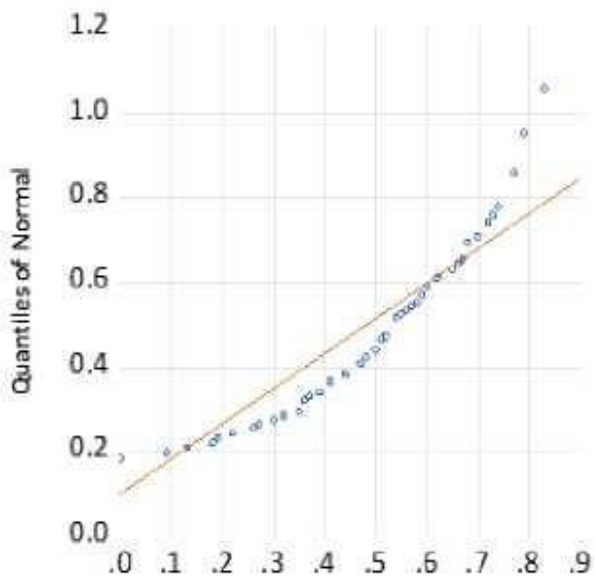

Quantiles of parent satisfaction

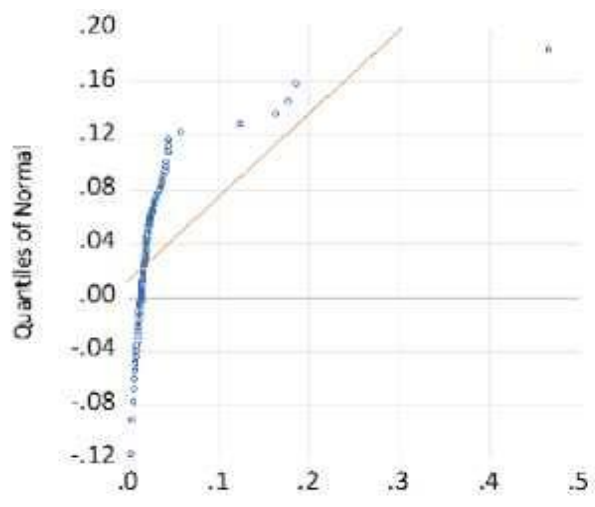

Quantiles of teacher participation

As can be seen from the graphs above, only the participation of teachers in the project presents problems as the values are far from the line that represents the normal distribution. This distribution is due to the fact that the values of this variable are very small, indicating the low level of teacher participation.

\subsection{Regression Results}

The following table shows the results of OLS regression for the three groupings of this study.

Table 1. Regression results for the sample: Students

Dependent Variable: student satisfaction 
Method: Least Squares

Date: 04/04/20 Time: 12:44

Sample: 177

Included observations: 77

\begin{tabular}{lllll}
\hline Variable & Coefficient & Std. Error & t-Statistic & Prob. \\
\hline C & 0.256411 & 0.076155 & 3.366949 & 0.0012 \\
disclosure & 0.023070 & 0.056126 & 0.411033 & 0.0223 \\
delegation & 0.082605 & 0.308577 & 0.267696 & 0.0097 \\
centralization of planning & -0.054521 & 0.099970 & -0.545375 & 0.0583 \\
the director's communication with & & & & \\
the & & & & \\
stockholders & 0.004132 & 0.150295 & 0.027493 & 0.0081 \\
teacher communication with & & & & \\
stakeholders & 0.038896 & 0.158399 & 0.245561 & 0.0068 \\
transactional leadership & -0.227166 & 0.090373 & -2.513658 & 0.0143 \\
transformational leadership & 0.154997 & 0.083503 & 1.856174 & 0.0077 \\
\hline R-squared & 0.193841 & Mean depende nt var & 0.189664 \\
$\begin{array}{l}\text { Adjusted R-squared } \\
\text { S.E. of regression }\end{array}$ & 0.112057 & S.D. dependent var & 0.219995 \\
Sum squared resid & 0.207303 & Akaike info criterion & -0.211175 \\
Log likelihood & 2.965248 & Schwarz criterion & 0.032337 \\
F-statistic & 16.13025 & Hannan-Quinn criter. & -0.113773 \\
Prob(F-statistic) & 2.370157 & Durbin-Watson stat & 0.694198 \\
\hline & 0.031300 & & & \\
\hline
\end{tabular}

First, at the beginning of the empirical study it is necessary to check the suitability of the model set up by this paper for the case of students. To perform this measurement, it is necessary to interpret the above table, obtained from the results of the statistical package that performed the processing of the data collected by the study sample.

As can be seen from the results, the coefficient of multiple $\mathrm{R}$ is $19.38 \%$. The $\mathrm{R}$ indicator is an indicator of the correlation of all dependent variables with the independent variable. The closer this value is, the stronger the connection. According to this criterion this indicator has a relatively good value considering that the number of explanatory variables is relatively high.

Second, before we raise the regression equation, we will study the coefficients to see which of the model variables are important. 
Table 2. Statistical significance of variables

\begin{tabular}{|l|l|l|}
\hline & variable & prob. \\
\hline & c & 0.0012 \\
\hline$X 1$ & disclosure & 0.0223 \\
\hline$X 2$ & delegation & 0.0097 \\
\hline$X 3$ & centralization of planning & 0.0583 \\
\hline$X 4$ & the director's communication with the stockholders & 0.0081 \\
\hline$X 5$ & teacher communication with stakeholders & 0.0068 \\
\hline$X 6$ & transactional leadership & 0.0143 \\
\hline$X 7$ & transformational leadership & 0.0077 \\
\hline
\end{tabular}

One-on-one testing of the importance of coefficients will be carried out by applying the following criterion.

$\mathrm{Xi}$ Ho: $01=0$ (01 statistically insignificant)

Ha: $0 \mathrm{i} * 0$ (0i statistically significant) $\quad$ t statistical $\quad \mathrm{p}=0.0223<a=0.05$

H0 goes down which means that the variable: Disclosure is statistically significant for our model:

X2 H0: $02=0$ (02 statistically insignificant)

Ha: $02 * 0$ (02 statistically significant) t statistical $p=0.0097>a=0.05$

H0 goes down which means that the variable: DELEGATION is statistically significant for our model:

The same analysis is done for all variables and it is concluded that all study variables included in this study are statistically significant for the model set up.

Finally, we move on to the interpretation of regression variables.

The regression coefficient for the Disclosure variable is +0.023 . This means that for one percent of the disclosure increase that executives make to contenders, student satisfaction will increase by $2.3 \%$, and the opposite for a Disclosure reduction unit that executives do to contenders will decrease student satisfaction by $2.3 \%$. This means that the disclosure that leaders make to applicants contributes positively to the level of student satisfaction. It must be acknowledged that this impact is relatively low.

The regression coefficient for the planning centralization variable is -0.054521 . It is seen that the contribution of planning centralization to the level of student satisfaction is negative. If the level of centralization of planning is reduced by $1 \%$, this will lead to an increase of $5.45 \%$ of student satisfaction. It can be considered that the decentralization of planning increases the overall satisfaction of students in schools. 
The same interpretation of the coefficients can be done analogously for other variables.

On the other hand, the results for the other two samples: (1) parents and (2) teachers are given below. The results are interpreted analogously as above.

Table 3. Regression results for sample: Parent

Dependent Variable: parent satisfaction

Method: Least Squares

Date: 04/04/20 Time: 12:45

Sample: 177

Included observations: 77

\begin{tabular}{lllll}
\hline Variable & Coefficient & Std. Error & t-Statistic & Prob. \\
\hline C & 0.387531 & 0.094204 & 4.113730 & 0.0001 \\
disclosure & 0.029392 & 0.069428 & 0.423344 & 0.0734 \\
delegation & -0.167169 & 0.381710 & -0.437948 & 0.0028 \\
centralization of planning & 0.008815 & 0.123664 & 0.071280 & 0.0434 \\
the director's communication with & & & & \\
the & & & & \\
stockholders & 0.022786 & 0.185915 & 0.122561 & 0.0028 \\
teacher communication with & & & & \\
stakeholders & 0.146265 & 0.195939 & 0.746484 & 0.0579 \\
transactional leadership & 0.085578 & 0.111791 & 0.765522 & 0.0466 \\
transformational leadership & 0.148373 & 0.103294 & 1.436420 & 0.0154 \\
\hline $\begin{array}{l}\text { R-squared } \\
\text { Adjusted } \text {-squared }\end{array}$ & 0.061449 & Mean depende nt var & 0.431948 \\
S.E. of regression & -0.033767 & S.D. dependent var & 0.252211 \\
Sum squared resid & 0.256434 & Akaike info criterion & 0.214205 \\
Log likelihood & 4.537340 & Schwarz criterion & 0.457717 \\
F-statistic & -0.246880 & Hannan-Quinn criter. & 0.311607 \\
Prob(F-statistic) & 0.645366 & Durbin-Watson stat & 1.858384 \\
\hline
\end{tabular}


$\mathrm{T}$ able 4. Results of regression for the samp le: Teacher

Dependent Variable: teacher participation

Method: Least Squares

Date: 04/04/20 Time: 12:46

Sample: 177

Included observations: 77

\begin{tabular}{lllll}
\hline \hline Variable & Coefficient & Std. Error & t-Statistic & Prob. \\
\hline \hline C & 0.387531 & 0.094204 & 4.113730 & 0.0001 \\
disclosure & 0.029392 & 0.069428 & 0.423344 & 0.0734 \\
delegation & -0.167169 & 0.381710 & -0.437948 & 0.0028 \\
centralization of planning & 0.008815 & 0.123664 & 0.071280 & 0.0434 \\
the director's communication with the & & & & \\
stockholders & 0.022786 & 0.185915 & 0.122561 & 0.0028 \\
teacher communication with stakeholders & 0.146265 & 0.195939 & 0.746484 & 0.0579 \\
transactional leadership & 0.085578 & 0.111791 & 0.765522 & 0.0466 \\
transformational leadership & 0.148373 & 0.103294 & 1.436420 & 0.0154 \\
\hline \hline R-squared & 0.061449 & Mean dependent var & 0.431948 \\
Adjusted R-squared & -0.033767 & S.D. dependent var & 0.252211 \\
S.E. of regression & 0.256434 & Akaike info criterion & 0.214205 \\
Sum squared resid & 4.537340 & Schwarz criterion & 0.457717 \\
Log likelihood & -0.246880 & Hannan-Quinn criter. & 0.311607 \\
F-statistic & 0.645366 & Durbin-Watson stat & 1.858384 \\
Prob(F-statistic) & 0.716876 & & & \\
\hline \hline
\end{tabular}

Table 5. Regression results for the three sample Students, parents and teachers

\begin{tabular}{|l|l|l|l|}
\hline & \multicolumn{3}{|l|}{ REGRESSION COEFFICIENTS } \\
\hline & $\begin{array}{l}\text { Student } \\
\text { satisfaction }\end{array}$ & $\begin{array}{l}\text { Parent } \\
\text { satisfaction }\end{array}$ & $\begin{array}{l}\text { leacher } \\
\text { participatio } \\
n\end{array}$ \\
\hline C & 0.256411 & 0.387531 & 0.020240 \\
\hline disclosure & 0.023070 & 0.029392 & 0.004570 \\
\hline delegation & 0.082605 & -0.167169 & 0.008564 \\
\hline centralization of planning & -0.054521 & 0.008815 & -0.025450 \\
\hline $\begin{array}{l}\text { the director's communication with the } \\
\text { stockholders }\end{array}$ & 0.004132 & 0.022786 & 0.021516 \\
\hline teacher communication with stakeholders & 0.038896 & 0.146265 & 0.213959 \\
\hline transactional leadership & -0.227166 & 0.085578 & -0.007775 \\
\hline transformational leadership & 0.154997 & 0.148373 & 0.044311 \\
\hline
\end{tabular}


What is interesting about comparing regression coefficients is as follows. First of all, Disclosure is considered positive for the integration of the school by all three study samples: teachers, students and parents. Parents score the highest. Second, the delegation coefficient is considered negative for school integration only by the parents. Third, centralization of

planning is considered negative with the exception of parents who consider it positive for school integration. Fourth, the communication of principals with stakeholders and the communication of teachers with stakeholders is considered positive for the integration of the school by the three study samples: teachers, students and parents. It is worth noting that the communication of teachers with stakeholders is considered more important for the integration of the school than the communication of principals with stakeholders. Finally, transformational leadership is considered more important than transactional leadership for school integration. The latter is considered too negative by students.

\section{Conclusions}

1. Educational institutions have for years focused on the qualification and training of teachers to raise them to the level of the requirements of new curricula. Relevant departments of high schools, national and local seminars, etc., present to teachers of all levels new teaching strategies, methods and techniques unknown, but more effective than traditional outdated practices.

2. Only alternative models, diverse strategies, different forms of teaching, interactive methods, individual programs, etc., facilitate the learning process in all students. It is the teacher's job to identify and use them.

3. The academic freedom of the teacher to select in the myriad of psych pedagogical and didactic innovations what seems most appropriate to him, what he can accomplish more easily in the conditions of the school and the classroom where he teaches, will turn into tradition effective experiences and will carry out updates of practices in the field of teaching and learning. The information and knowledge that students receive through various means is often uncontrollable and creates a vicious circle. The teacher is one of the actors who should contribute to getting out of this circle.

4. Information and communication technology, present in all schools of the country, constitutes a reform in teaching and supports all actors for a learning that meets the required standards of achievement. Educational institutions require commitment that every teacher recognizes and uses ICT for the benefit of the learning process.

5. It cannot be claimed that there is an absolute division between the traditional and the contemporary. It does not matter more what the teacher follows, the work and the activities that are performed, than what is achieved by the students and the teacher, whether this is verified and whether everyone gets 
the evaluation for what they fulfill. The center of gravity remains in the realization of the roles of the actors of the lesson. Any strategy, method or technique, contemporary or traditional, is ineffective and unsuccessful if it does not give the teacher the expected expectations.

6. Recipes cannot be given by anyone and at any time. Any strategy, method or technique, contemporary or traditional, is ineffective and unsuccessful if it does not meet the teacher's expectations. Only that professional updating, for sure, has an impact on student achievement.

\section{Bibliography}

[1] AEDP. (1998). Studiogjithfka, arsyes vendin e pare (Permbledhje artikujsh). Tirane.

[2] Blaufusa', K., Mohlmannb, A., \& Schwabeaa, A. N. (2019). Stock price reactions to news about corporate tax avoidance andevasion. Journal of Economic Psychology, 72, 278-292.

[3] CDE. (2005). Mesimdhenia dhe te nxenet nderveprues - Modele per zhvillimine te menduarit kritik (Shkencat shoqerore, per klasat 6-12). Tirane.

[4] CDE. (2008). Mesimdhenia dhe te nxenet nderveprues - Modele per zhvillimine te menduarit kritik. Tirane.

[5] Chan, W. S. (2003). Stock price reaction to news and no-news: drift and reversal after headlines. Journal of Financial Economics, 70 , 223-260.

[6] Council_of_Europe. (2008). Policies and practicies for teaching sociocultural diversity - A survey report. Strasbourg: Council of Europe Publishing.

[7] Council_of_Europe. (2010). Policies and practicies for teaching sociocultural diversity -A framework of teacher competences for engaging With diversity,.

[8] Dispozita Normative. (2002). Tirane.

[9] European_Commission. (2004). Interim Evaluation Report on the Results Achieved and on the Qualitative and Quantitative Aspects of the Implementation of the Second Phase of the Community Action Programme in the Field of Education 'Socrates', 153.

[10] European_Commission. (2006). The Bologna Proc ess - Towards the European Higher Education Area, http://ec.europa.eu/education/highereducation/doc1290_en.htm (Accessed: 20.12.2013)

[11] Eurydice. (2010). Focus on higher education in Europe 2010: The impa ct of the Bologna proces $s$.

[12] http://eacea.ec.europa.eu/education/eurydice/documents/thematic_reports /122EN.p df. (Accessed: 20.12.2013).

[13] Gardner, H. (2003). Mendja e pashkolluar. Tirane.

[14] Greene, W. H. (2018). Econometric Analysis. Pearson .

[15] Grup_autoresh. (1986). Didaktika. Tirane.

[16] Grup_autoresh. (1995). Strategjite e te mesuarit. Tirane.

[17] Grup_autoresh. (2001). Modele per mesimdhenie te suksesshme. Tirane. 
[18] Grup_autoresh. (2002). Kur arsimi levronte shpirtin. Tirane.

[19] H, E. (2003). The European Union and Education and Training: An Overview of Policies and Initiatives, David Philips (comp.), A Comparative Study of Issues in Four Member States icinde Secaucus, NJ: Kluwer Akademic Publisher, ss.13-39. [20] Horvath, Z. (2007). Handbook On The European Union Hungarian National Assembly. http://ec.europa.eu/education/404_en.htm(Accessed: 21.12.2013) .

[21] Instituti_i_Kurrikules_dhe_i_Trajnimit. (2008). Drejtimi i shkolles, udhezues per drejtuesit e shkolles. Tirane.

[22] Instituti_i_kurrikules_dhe_i_Trajnimit. (2009). Korniza e kurrikules se gjimnazit. Tirane.

[23] Instituti_i_Kurrikules_dhe_i_Trajnimit. (2009). Vleresimi i nxenesit-Manual per mesuesit. Tirane.

[24] Instituti_i_Kurrikules_dhe_i_Trajnimit. (2010). Udhezuesi per zhvillimin e kurrikules se re te gjimnazit. Tirane.

[25] ISP, \& UNESCO. (2003). Edukimi nderkulturor dhe i te drejtave te njeriut ne shkolle - Nje bote per t'u zbuluar..., Manual per mesuesit e shkolles se mesme.

[26] Kraja, M. (2008). Pedagogji ezbatuar. Tirane.

[27] LigjiNr.7952, dt.21.06.1995 "Per sistemin arsimorparauniversitar" i ndryshuar me ligjin Nr. 8387, date30.07.1998; ligjin Nr.8872, date29.03.2002; ligjin Nr.9903, date 17.04.2008; ligjin Nr.9985, date 11.09.2008.. (n.d.).

[28] MASH, \& Save_the_Children. (2005). Manual inspektimi i plote i shkolles. Tirane.

[29] MASH, \& Save_the_Children. (2007). Manual vetevleresimi i shkolles. Tirane.

[30] Mesimdhenia me ne qender nxenesin. Tirane. (12 janar 2009). Gazeta Zeri i dites.

[31] Misha, A. (2003). Vleresimi i shkolles. Tirane.

[32] Muka, P. (1995). Te mesuarit me objektiva dhe modeli A - 94. Tirane.

[33] Musai, B. (2000). Metodologji e mesimdhenies. Tirane.

[34] Orstein, A. C. (2003). Kurrikula, bazat, parimet dhe problemet. Tirane. 